\title{
Muscle pathology in 31 patients with calpain 3 gene mutations
}

\section{Zmiany histopatologiczne w biopsii mięśnia u 31 chorych z mutacjami w genie kodującym kalpainę 3}

\author{
Aleksandra A. Nadai|-Pakleza ${ }^{1,2}$, Małgorzata Dorobek ${ }^{3,4}$, Klaudia Nestorowizz', Barbara Ryniewizz', Elżbieta Szmidt-Sałkowska', \\ Anna M. Kamińska ${ }^{1,3}$ \\ 'Department of Neurology, Medical University of Warsaw, Poland \\ 2Centre de Référence des Maladies Neuromusculaires Nantes/Angers, Service de Neurologie, Centre Hospitalier Universitaire d'Angers, France \\ ${ }^{3}$ Neuromuscular Unit, Mossakowski Medical Centre, Polish Academy of Sciences, Warsaw, Poland \\ ${ }^{4}$ Department of Neurology, CSK MSWiA, Warsaw, Poland
}

Neurologia i Neurochirurgia Polska 2013; 47, 3: 214-222

DOI: 10.5114/ninp.2013.35490

\begin{abstract}
Background and purpose: At present, more than 20 different forms of limb-girdle muscular dystrophies (LGMDs) are known (at least 7 autosomal dominant and 14 autosomal recessive). Although these different forms show some typical phenotypic characteristics, the existing clinical overlap makes their differential diagnosis difficult. Limb-girdle muscular dystrophy type 2 (LGMD2A) is the most prevalent LGMD in many European as well as Brazilian communities and is caused by mutations in the gene $C A P N 3$. Laboratory testing, such as calpain immunohistochemistry and Western-blot analysis, is not totally reliable, since up to $20 \%$ of molecularly confirmed LGMD2A show normal content of calpain 3 and a third of LGMD2A biopsies have normal calpain 3 proteolytic activity in the muscle. Thus, genetic testing is considered as the only reliable diagnostic criterion in LGMD2A. Material and methods: In an attempt to find a correlation between genotype and muscle pathology in limb-girdle muscular dystrophy 2A we performed histopathological investigation of a group of 31 patients subdivided according to the type of pathologic CAPN3 gene mutation.

Results: In all biopsies typical features of muscular dystrophy such as fiber necrosis and regeneration, variation in fiber size and fibrosis were noted. Lobulated fibers were often
\end{abstract}

\section{Streszczenie}

Wstęp i cel pracy: Dotychczas opisano ponad 20 różnych form dystrofii obręczowo-kończynowej (limb girdle muscular dystrophy - LGMD) (co najmniej 7 rodzajów o dziedziczeniu autosomalnym dominującym oraz 14 o dziedziczeniu autosomalnym recesywnym). Pomimo że część z tych chorób można różnicować na podstawie obrazu klinicznego, diagnostykę utrudnia często podobieństwo objawów. Dystrofia obręczowo-kończynowa typu 2A (limb-girdle muscular dystrophy type 2 LGMD2A), najczęstsza dystrofia mięśniowa w wielu społecznościach (np. w Europie i Brazylii), spowodowana jest przez mutacje w genie kalpainy 3 (CAPN3). Badanie immunohistochemiczne kalpainy czy też metodą Western blot nie są wystarczające do ustalenia właściwego rozpoznania (w odpowiednio $1 / 3$ i $20 \%$ potwierdzonych genetycznie LGMD2A badania te wypadają prawidłowo). Podstawę rozpoznania tej miopatii stanowi badanie genetyczne.

Materiał i metody: W pracy przedstawiono wyniki badania zależności między genotypem a analizą histopatologiczną biopsji mięśnia u 31 chorych na LGMD2A. Chorzy podzieleni zostali na grupy według wyników badania genetycznego genu $C A P N 3$ odpowiedzialnego za tę chorobę.

Wyniki: We wszystkich badanych biopsjach stwierdzano typowe zmiany dystroficzne, takie jak obecność włókien martwiczych

Correspondence address: Aleksandra Nadaj-Pakleza, Centre de Référence des Maladies Neuromusculaires Nantes/Angers, Service de Neurologie, CHU d'Angers 4, rue Larrey, 49933 Angers, France, e-mail: anadpak@gmail.com

Received: 21.12.2011; accepted: 10.10.2012 
encountered in the muscle biopsies of LGMD2A patients. Such fibers were more frequent in patients with $550 \mathrm{del} A$ mutation.

Conclusions: These findings may be helpful in establishing diagnostic strategies in LGMD.

Key words: limb girdle muscular dystrophy, $C A P N 3$, calpain, muscle biopsy.

\section{Introduction}

Limb girdle muscular dystrophies (LGMDs) represent a heterogeneous group of disorders with variable clinical and genetic features. Limb girdle muscular dystrophies are characterized clinically by progressive muscle weakness and atrophy mainly of the pelvic and shoulder girdle muscles but without affecting facial muscles. The clinical course may be variable, ranging from severe forms with early onset and rapid progression to milder forms with later onset and minor physical disability $[1,2]$. However, in all cases serum creatine kinase is elevated and a dystrophic pattern with necrosis and regeneration on the muscle biopsy is observed. At present, more than 20 different forms of LGMDs are known (at least 7 autosomal dominant and 14 autosomal recessive) [3]. Although these different forms show some typical phenotypic characteristics, the existing clinical overlap makes their differential diagnosis difficult $[3,4]$. Laboratory testing, such as calpain immunohistochemistry [5] and Western-blot analysis, is not totally reliable, since up to $20 \%$ of molecularly confirmed limb-girdle muscular dystrophy type 2 (LGMD2A) show normal content of calpain 3 [6-9] and a third of LGMD2A biopsies have normal calpain 3 proteolytic activity in the muscle [10]. Thus, genetic testing is considered as the only reliable diagnostic criterion in LGMDs [11-14].

A classic LGMD2 phenotype was described by Fardeau in 1996 [15] in a small community living in the Reunion Island. Since then, LGMD2A has been identified in many countries [3,13,21-24]. Subsequently, wide intra- and interfamilial variability has been reported $[8,14,25,26]$. Limb-girdle muscular dystrophy type 2 is the most prevalent LGMD in many European as well as Brazilian communities [20,21,23,27,28].

Mutations in the calpain (CAPN3) gene have been proven to be responsible for LGMD2A (MIM\# 53600) $[29,30]$. Until now, more than 160 pathogenic muta- i regenerujących, zróżnicowaną wielkość włókien oraz włóknienie. Włókna o nierównomiernym rozkładzie barwień na enzymy oddechowe (lobulated fibers) były często obserwowane w biopsjach chorych z LGMD2A. Tego typu włókna szczególnie często występowały u chorych z mutacją 550delA.

Wnioski: Wyniki pracy wnoszą nowe informacje ułatwiające diagnostykę LGMD.

Słowa kluczowe: dystrofia obręczowo-kończynowa, $C A P N 3$, kalpaina, biopsja mięśni.

tions have been identified. However, lack of defined mutational hotspots makes molecular analysis laborious and expensive [14].

Calpain 3 is a skeletal, muscle specific, $\mathrm{Ca}^{2+}$-activated neutral protease [30]. The physiological role of calpain 3 in muscle cell is still uncertain [14]. Spencer et al., [25] and Keira et al. [31] described calpain 3 binding to the $\mathrm{N} 2$ and $\mathrm{M}$-line regions of titin. This binding is thought to stabilize calpain 3, preventing its autolysis. It has been shown that calpain 3 is involved in the disassembly of myofibrils during early stages of turnover [32] and plays a role in the postfusion defect in muscle maturation and differentiation $[33,34]$. As for the LGMD2 pathological mechanism, it is now well accepted that loss of function mutation leads to abnormal sarcomere formation and impairment of muscle protein capacity [35].

Numerous myopathological changes typical for muscular dystrophy have been described in LGMD2A patients $[19,36,37]$. Basic histological and histochemical features of the muscle biopsy are relatively non-specific. However, the presence of abnormal lobulation of type 1 fibers in the end stage of the disease was found by Fardeau et al. [15] already in the Reunion Island patients. Subsequently, the high proportion of lobulated fibers in muscle biopsy was considered as a hallmark of pathological lesions of calpainopathy $[38,39]$.

Fanin et al. [40] in their description of 24 LGMD2A patients found significantly lower levels of dystrophic features (i.e. degenerating and regenerating fibers) and higher levels of chronic changes (i.e. lobulated fibers) as compared with other types of LGMD2A. Lobulated fibers, so called because of their peculiar pattern of oxidative enzyme reaction on histochemical preparations, represent a non-specific muscle pathology, observed in a variety of neuromuscular disorders [41]. They have been described in both genetic (facioscapulohumeral muscular dystrophy, Duchenne carrier, alpha-sarcoglycanopathy, myotonic dystrophy type 2) $[10,42,43]$ and acquired myopathies (dermatomyositis, polymyositis and 
adult nemaline myopathy) [44-47]. Interestingly, they were also reported in neurogenic muscle disease [48] and dystonia [49].

The exact pathomechanism leading to the formation of lobulated fibers remains to be elucidated. In LGMD2A, the loss of calpain activity on myofibrils leads to incomplete muscle maturation and this hypothesis is currently taken into consideration $[25,38]$. The question of selective involvement of type 1 muscle fibers still remains unanswered.

To provide detailed histopathological characteristics in a large group of patients with calpainopathy, we evaluated muscle biopsies of 31 patients with genetically proven LGMD2A.

\section{Material and methods}

\section{Patients}

Out of our group of 68 patients with genetically proven LGMD2A, we have studied 31 cases (15 females and 16 males) who had a muscle biopsy taken for diagnostic purposes during the period from 1992 to 2002.

Table 1. Clinical and genetic description of subjects. Group 1: Patients with homozygous del550A mutation

\begin{tabular}{|c|c|c|c|}
\hline $\begin{array}{c}\text { Patient } \\
\text { number }\end{array}$ & Sex & $\begin{array}{c}\text { Age at } \\
\text { onset }\end{array}$ & $\begin{array}{l}\text { Age at } \\
\text { biopsy }\end{array}$ \\
\hline 1 & $\mathrm{~F}$ & 12 & 12 \\
\hline 2 & $\mathrm{M}$ & 14 & 23 \\
\hline 3 & $\mathrm{~F}$ & 12 & 14 \\
\hline 4 & $\mathrm{~F}$ & 13 & 15 \\
\hline 5 & $\mathrm{M}$ & 9 & 17 \\
\hline 6 & $\mathrm{M}$ & 6 & 13 \\
\hline 7 & $\mathrm{~F}$ & 18 & 25 \\
\hline 8 & $\mathrm{M}$ & 12 & 14 \\
\hline 9 & $\mathrm{~F}$ & 11 & 13 \\
\hline 10 & $\mathrm{~F}$ & 12 & 16 \\
\hline 11 & $\mathrm{~F}$ & 10 & 27 \\
\hline 12 & $\mathrm{~F}$ & 5 & 18 \\
\hline 13 & $\mathrm{M}$ & 14 & 15 \\
\hline 14 & $\mathrm{M}$ & 14 & 14 \\
\hline 15 & $\mathrm{~F}$ & 2 & 23 \\
\hline 16 & $\mathrm{M}$ & 11 & 12 \\
\hline
\end{tabular}

There was no family history of myopathy in all diagnosed patients.

\section{Molecular genetic analysis: DNA testing for calpain 3 gene mutations}

Mutation analysis in the CAPN3 gene was done by single strand conformation polymorphism (SSCP) and heteroduplex (HE) analysis according to previously described procedures $[30,50]$. Polymerase chain reaction products revealing an abnormal $\mathrm{SSCP} / \mathrm{HE}$ migration pattern were directly sequenced on an ABI PRISM 377 automated fluorescent DNA sequencer (Applied Biosystems) in the DNA Sequencing and Oligonucleotide Synthesis Laboratory, IBB PAN, Warsaw, Poland.

\section{Muscle biopsy specimens}

A muscle biopsy was performed on the vastus femoris muscle in all patients according to a previously described method [51]. Detailed data on light microscopic evaluations were performed on transverse sections conventionally stained with hematoxylin-eosin (H\&E), Gomori trichrome, NADH dehydrogenase, succinic dehydrogenase $(\mathrm{SDH})$, lactic dehydrogenase $(\mathrm{LDH})$ and ATPase after preincubation at $\mathrm{pH} 9.4$ and 4.35 .

For the purpose of this study, all samples were reevaluated by two authors in non-blinded analysis (A.N.-P. and A.K.). Pathological changes such as necrosis and regeneration, fibrosis, hyaline fibers, ring fibers and muscle fiber type composition were assessed semiquantitatively in every case. Changes were graded on a 4-point scale: none $(-)$, mild $(+)$, moderate $(++)$, or advanced $(+++)$. Necrosis and other structural changes were assessed in selected areas in $\mathrm{H} \& \mathrm{E}$ staining, whereas fiber type composition and lobulated fibers were assessed in serial sections in the same area in $\mathrm{SDH}$.

Lobulated fibers were defined as fibers with a cha racteristic peculiar pattern of oxidative enzyme reaction on histochemical preparations.

As for fiber type composition [52], the following approximate proportions were accepted: type $1-30-40 \%$ and type $2-60-70 \%$.

\section{Results}

Clinical and genetic data of 31 patients are summarized in Tables 1, 2 and 3. 
Table 2. Clinical and genetic description of subjects. Group 2: Patients with different homozygous mutations other than del550A

\begin{tabular}{|ccccl|}
\hline $\begin{array}{c}\text { Patient } \\
\text { number }\end{array}$ & Sex & $\begin{array}{c}\text { Age at } \\
\text { onset }\end{array}$ & $\begin{array}{c}\text { Age at } \\
\text { biopsy }\end{array}$ & Mutation \\
\hline 1 & M & 2 & 11 & hz 418dupC,fs \\
\hline 2 & M & 8 & 14 & hz 418dupC,fs \\
\hline 3 & M & 20 & 30 & hz 598-612del15ntd Phe200_Leu204del \\
\hline 4 & F & 11 & 12 & hz 598-612del15ntd Phe200_Leu204del \\
\hline 5 & M & 13 & 18 & hz 598-612del15ntd Phe200_Leu204del \\
\hline
\end{tabular}

Table 3. Clinical and genetic description of subjects. Group 3: Patients with different heterozygous mutations

\begin{tabular}{|ccccl|}
\hline $\begin{array}{c}\text { Patient } \\
\text { number }\end{array}$ & Sex & $\begin{array}{c}\text { Age at } \\
\text { onset }\end{array}$ & $\begin{array}{c}\text { Age at } \\
\text { biopsy }\end{array}$ & Mutation \\
\hline 1 & F & 10 & 12 & htz del550A, 2242C > T Arg 748stop \\
\hline 2 & M & 7 & 9 & 02 htz del550A, htz del598-612, The 200-204 FWSAL \\
\hline 3 & F & 10 & 15 & htz del550A, htz509A > G Tyr170Cys(new) \\
\hline 4 & M & 13 & 15 & htz del550A, 2242C > T Arg 748stop \\
\hline 5 & F & 12 & 15 & htz del550A, htz649G $>$ A, Glu 217Lys \\
\hline 6 & M & 12 & 15 & htz del550A, 1722delC fs(new) \\
\hline 7 & F & 15 & 19 & htz del550A, htz del598-612, The 200-204 \\
\hline 8 & M & 6 & 6 & htz del550A, htz1356insT,fs \\
\hline 9 & M & 14 & 20 & htz 1063C > T Arg355Trp, htz 1194-9A > G fs \\
\hline 10 & M & 10 & 10 & htz del550A, 418dupC fs \\
\hline F-female, M- male & & & &
\end{tabular}

All patients were sporadic and had limb-girdle clinical phenotype. Patients were divided according to the mutation. In 16 patients, the homozygous occurrence of 550 delA mutation was detected (group 1). In 5 patients different homozygous mutations other than 550delA were demonstrated (group 2) and the remaining $10 \mathrm{pa-}$ tients were compound heterozygotes for previously described mutations in the CAPN3 gene (group 3).

Group 1 (Table 1) consisted of 16 patients $(9$ males and 7 females). The mean age at onset of muscle symptoms was 10.9 years (range: 2-18 years). Group 2 (Table 2) consisted of 5 patients ( 1 female and 4 males). The mean age at onset was 12.5 years (range: $6-15$ years). Group 3 (Table 3) consisted of 10 patients ( 4 females and 6 males). The mean age of onset was 15 years (range: 2-20 years).

All examined patients had myopathic changes in muscle biopsy. A constant feature, observed in all examined biopsies, was increased variability in fiber size and fibrosis. The other common feature typical for muscu- lar dystrophy was fiber necrosis (27/31) and regeneration (30/31). Only one biopsy showed neither necrosis nor regeneration. The occurrence of hyaline fibers was frequent (21/31), whereas ring fibers were rarely encountered $(5 / 31)$.

Intensity of all analyzed histopathological changes varied from 'none' to 'advanced' and seemed not to be correlated with either age of the patient or the duration of the disease. It was noted, however, that in group 1 fibrosis tended to increase as the disease progressed. No such relationship was observed in other groups. Occurrence of lobulated fibers was found in more than half of the biopsies (17/31). Such fibers behaved mostly as type 1 fibers.

No significant differences were observed between groups with different mutations except for the high percentage of lobulated fibers in group 1 (patients homozygous for del550A mutation). In this group, lobulated fibers were noted in almost $2 / 3$ of cases (10/16). No correlation between the duration of the disease and the 


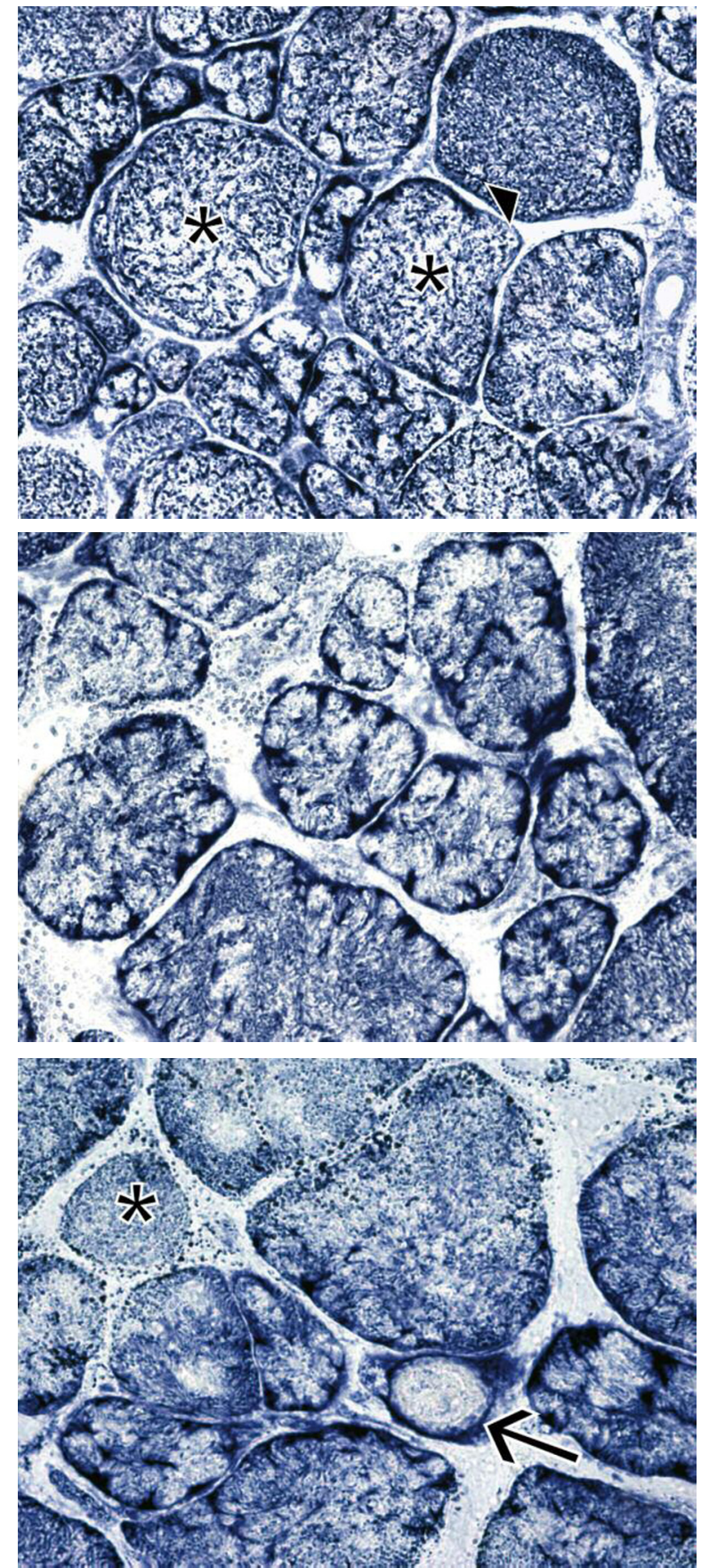

Fig. 1. Multiple lobulated fibers with irregular aggregations of oxidative activity within the cytoplasm. Note also the presence of the ring fiber (arrow) as well as the presence of normal type I (arrowheads) and type 2 (asterisk) fibers. Succinic dehydrogenase $\times 20$

number of lobulated fibers was noted. For instance, in the group of 4 patients with longstanding disease ( $<10$ years) only 1 had lobulated fibers. In group 2 , only 1 of 5 biopsies showed the occurrence of lobulated fibers. In group 3, lobulated fibers were noted in half of the patients. Type 1 fiber predominance was observed in one third of biopsies (10/31) while type 2 fiber predominance was very seldom seen $(3 / 31)$.

Lobulated muscle fibers were characterized by an irregular pattern of oxidative enzyme reaction in light microscopy (Fig. 1). Most of them were atrophied and behaved as type 1 fibers.

\section{Discussion}

In our analysis, we confirmed the presence of typical dystrophic pathological changes in the muscle biopsies with genetically proven LGMD2A. As in other muscular dystrophies, LGMD2A muscles show active necrotic and regenerating processes resulting, as the disease progresses, in increased fiber size variation and fibrosis. The intensity of the dystrophic process did not vary across the three groups with different mutations and seemed not to correlate with the age of the onset and disease duration, except for more pronounced fibrosis in patients with longstanding disease.

Histopathological investigations of muscle biopsies in LGMD2A patients are scarce $[19,26,36,53]$. Three of these studies $[19,36,53]$ dealt with systematic reviews, whereas Vainzof et al. [24] described preclinical histopathological changes in muscle biopsies from members of a large consanguineous family. Chae et al. [36] in all patients with CAPN3 mutations found the typical feature of muscular dystrophy with less active necrosis and prominent fibrosis in the advanced stages of the disease. Similar observations were presented by Hermanova et al. [19]. In a group of 12 LGMD2A patients, a less active necrotic process was observed in patients with longstanding disease. The extent of fibrosis, however, correlated with the disease duration.

According to Fanin et al. [53], in their series of 24 LGMD2A patients the level of dystrophic features (i.e. degenerating and regenerating fibers) was significantly lower than in other types of LGMD2. The authors also found a direct correlation between the extent of muscle fiber degeneration and regeneration and disease progression. In their group, the histopathology severity score seemed not to be correlated with disease duration.

Yet, a correlation between the extent of fibrosis and disease duration was found in our patients only in subgroup 1 of LGMD2A homozygous for del550A mutation. No such correlations were found in the other subgroups.

There are only a few studies that have analyzed the presence of lobulated fibers in genetically confirmed 
Table 4. Occurrence of muscle histopathological changes in patients with homozygous del550A mutation (Group 1)

\begin{tabular}{|c|c|c|c|c|c|c|c|c|}
\hline No & $\begin{array}{c}\text { Fiber type } \\
\text { pre- } \\
\text { dominance }\end{array}$ & Necrosis & Regeneration & $\begin{array}{l}\text { Increase } \\
\text { in fiber } \\
\text { variability }\end{array}$ & $\begin{array}{l}\text { Hyaline } \\
\text { fibers }\end{array}$ & Fibrosis & $\begin{array}{c}\text { Ring } \\
\text { fibers }\end{array}$ & $\begin{array}{l}\text { Lobulated } \\
\text { fibers }\end{array}$ \\
\hline 1 & Type 1 & + & + & + & +++ & ++ & - & ++ \\
\hline 2 & Type 1 & +++ & +++ & +++ & ++ & + & - & - \\
\hline 3 & Type 1 & + & +++ & ++ & + & + & - & - \\
\hline 4 & Type 1 & ++ & +++ & ++ & ++ & + & - & + \\
\hline 5 & Type 1 & +++ & +++ & ++ & ++ & ++ & + & - \\
\hline 6 & Type 1 & + & ++ & ++ & - & + & - & +++ \\
\hline 7 & - & + & ++ & ++ & ++ & +++ & ++ & ++ \\
\hline 8 & - & +++ & +++ & +++ & + & +++ & - & + \\
\hline 9 & - & + & +++ & + & + & ++ & - & - \\
\hline 10 & - & + & + & ++ & - & ++ & - & +++ \\
\hline 11 & - & - & ++ & + & +++ & +++ & - & - \\
\hline 12 & Type 2 & + & + & + & +++ & + & + & +++ \\
\hline 13 & Type 2 & + & ++ & + & + & + & - & - \\
\hline 14 & - & + & ++ & + & ++ & + & - & ++ \\
\hline 15 & - & - & ++ & ++ & + & + & - & + \\
\hline 16 & - & ++ & ++ & + & - & + & - & + \\
\hline
\end{tabular}

Table 5. Occurrence of muscle histopathological changes in patients with different homozygous mutations other than del550A (Group 2)

\begin{tabular}{|c|c|c|c|c|c|c|c|c|}
\hline No & $\begin{array}{c}\text { Fiber type } \\
\text { pre- } \\
\text { dominance }\end{array}$ & Necrosis & Regeneration & $\begin{array}{l}\text { Increase } \\
\text { in fiber } \\
\text { variability }\end{array}$ & $\begin{array}{l}\text { Hyaline } \\
\text { fibers }\end{array}$ & Fibrosis & $\begin{array}{l}\text { Ring } \\
\text { fibers }\end{array}$ & $\begin{array}{l}\text { Lobulated } \\
\text { fibers }\end{array}$ \\
\hline 1 & - & - & - & ++ & + & + & - & - \\
\hline 2 & - & ++ & ++ & ++ & + & ++ & + & ++ \\
\hline 3 & Type 1 & - & - & + & - & + & - & - \\
\hline 4 & - & +++ & +++ & ++ & ++ & ++ & - & - \\
\hline 5 & - & + & ++ & + & ++ & +++ & - & - \\
\hline
\end{tabular}

LGMD2A patients. None of them, however, correlated the histopathological findings with the type of $C A P N 3$ mutation. Chae et al. [36] found a high proportion (67\%) of lobulated fibers in his series of 21 patients as well as a positive correlation between the number of lobulated fibers and the stage of the disease.

Hermanova et al. [19], in their material of 14 muscle biopsies, revealed lobulated fibers in half of the specimens. They observed that most lobulated fibers were found in muscle biopsies performed after a longstanding disease course and were not found in the early stages of the disease. Fanin's findings [53] also confirmed the occurrence of lobulated fibers in a high percentage of cases (13 from a group of 24 patients). Similarly, they observed a correlation between the number of lobulated fibers and disease duration.

In our patients, lobulated fibers were found in more than half of the biopsies in the group of 31 LGMD2A cases. No obvious association between lobulated fibers and disease duration was observed in the analyzed group.

We performed the first, to our knowledge, histopathological investigation of a group of LGMD2A patients, subdivided according to the type of pathogenic mutation. 
Table 6. Occurrence of muscle histopathological changes in patients with different heterozygous mutations (Group 3)

\begin{tabular}{|c|c|c|c|c|c|c|c|c|}
\hline No & $\begin{array}{c}\text { Fiber type } \\
\text { pre- } \\
\text { dominance }\end{array}$ & Necrosis & Regeneration & $\begin{array}{c}\text { Increase } \\
\text { in fiber } \\
\text { variability }\end{array}$ & $\begin{array}{l}\text { Hyaline } \\
\text { fibers }\end{array}$ & Fibrosis & $\begin{array}{c}\text { Ring } \\
\text { fibers }\end{array}$ & $\begin{array}{l}\text { Lobulated } \\
\text { fibers }\end{array}$ \\
\hline 1 & Type 1 & ++ & + & + & ++ & ++ & - & +++ \\
\hline 2 & - & ++ & + & + & + & + & + & +++ \\
\hline 3 & - & - & + & ++ & - & + & - & - \\
\hline 4 & - & ++ & + & + & - & ++ & - & - \\
\hline 5 & - & ++ & ++ & ++ & + & + & - & - \\
\hline 6 & Type 1 & ++ & ++ & ++ & - & + & - & +++ \\
\hline 7 & - & ++ & +++ & +++ & + & + & - & + \\
\hline 8 & Type 1 & ++ & ++ & ++ & - & + & - & - \\
\hline 9 & Type 2 & + & + & +++ & - & + & - & ++ \\
\hline 10 & - & + & + & + & - & + & - & - \\
\hline
\end{tabular}

The only relation we found was a higher occurrence of lobulated fibers in patients homozygous for del550A mutation.

Genotype-phenotype correlations in LGMD2A have been described so far in only two papers $[19,53]$. Fanin et al. [53], however, concentrated on the relationship between genotype and protein content in muscle. Saenz et al. [50] analyzed the clinical status of patients with different mutations and suggested that patients with homozygous mutations tend to have a more severe phenotype and faster clinical course. Neither of these studies took muscle morphology into consideration.

Limb-girdle muscular dystrophy type 2 remains one of the most difficult of all recessive LGMDs to diagnose. The variability of clinical phenotype, incomplete sensitivity and specificity of calpain 3 protein biochemical analysis [30], and the effort required to identify point mutations in a relatively large gene make the diagnostic process a complicated, laborious and expensive task. Yet, an unequivocal diagnosis is necessary, both when offering genetic counseling and when selecting patients for future clinical trials with drug or gene therapy.

\section{Conclusions}

In our opinion, distinguishing the patterns of muscle histopathological changes in LGMD2A is a very informative step in clinical diagnosis, helpful in establishing diagnostic strategies in LGMD patients.

\section{Acknowledgements}

The research was supported by the State Committee for Scientific Research (grant number 6P05B07120) of the Polish Ministry of Scientific Research and Information Technology.

\section{Disclosure}

Authors report no conflict of interest.

\section{References}

1. Angellini C., Nardetto L., Borsato C., et al. The clinical course of calpainopathy (LGMD2A) and dysferlinopathy (LGMD2B). Neurol Res 2010; 32: 41-46.

2. Pogoda T.V., Krakhmaleva I.N., Lipatova N.A., et al. High incidence of $550 \mathrm{del}$ A of calpain3 in LGMD2A patients from Russia. Hum Mut 2000; 15: 295.

3. Bushby K. Diagnosis and management of the limb girdle muscular dystrophies. Pract Neurol 2009; 9: 314-323.

4. Kramerova I., Beckmann J., Spencer M.J. Molecular and cellular basis of calpainopathy (limb girdle muscular dystrophy type 2A). Bioch Biophys Acta 2007; 1772: 128-144.

5. Kolski H.K., Hawkins C., Zatz M., et al. Diagnosis of limbgirdle muscular dystrophy $2 \mathrm{~A}$ by immunohistochemical techniques. Neuropathology 2008; 28: 264-268.

6. Anderson L.V., Davison K., Moss J.A., et al. Characterization of monoclonal antibodies to calpain 3 and protein expression in muscle from patients with limb-girle muscular dystrophy type 2A. Am J Pathol 1998; 153: 1169-1179. 
7. Charlton R., Henderson M., Richards J., et al. Immunohistochemical analysis of calpain3: advantages and limitations in diagnosing LGMD2A. Neuromuscul Disord 2009; 19: 449-457.

8. Fanin M., Nascimbeni A.C., Tasca E., et al. How to tackle the diagnosis of limb-girdle muscular dystrophy 2A. Eur J Hum Genet 2009; 17: 598-603.

9. Sorimachi H., Imajoh-Omi S., Emori Y., et al. Muscle-specific calpain, p94, responsible for limb-girdle muscular dystrophy type $2 \mathrm{~A}$, associates with connectin through IS2, a p94-specific sequence. J Biol Chem 1995; 270: 31158-31162.

10. Ono Y., Sorimachi H., Suzuki K. New aspect of the research on limb-girdle muscular dystrophy 2A: a molecular biologic and biochemical approach to pathology. Trends Cardiovasc Med 1999; 9: 114-118.

11. Fanin M., Nascimbeni A.C., Angelini C. Screening of calpain-3 autolytic activity in LGMD muscle: a functional map of CAPN3 gene mutations. J Med Genet 2007; 44: 38-43.

12. Groen E.J., Charlton R., Barresi R., et al. Analysis of the UK diagnostic strategy for limb girdle muscular dystrophy 2A. Brain 2007; 130: 3327-3249.

13. Manzur A.Y., Muntoni F. Diagnosis and new treatments of muscular dystrophies. J Neurol Neurosurg Psychiatry 2009; 80: 706-714

14. Piluso G., Politano L., Aurino S., et al. Extensive scanning of the calpain-3 gene broadens the spectrum of LGMD2A phenotypes. J Med Genet 2005; 42: 686-693.

15. Fardeau M., Hillaire D., Mignard C., et al. Juvenile limb-girdle muscular dystrophy. Clinical, histopathological and genetic data on a small community living in the Reunion Island. Brain 1996; 119: 295-308.

16. Canki-Klain N., Milic A., Kovac B., et al. Prevalence of the 550 delA mutation in calpainopathy (LGMD2A) in Croatia. Am J Genet A 2004; 125A: 152-156.

17. Duno M., Sveen M.L., Schwartz M., et al. cDNA analyses of CAPN 3 enhance mutation detection and reveal a low prevalence of LGMD2A patients in Denmark. Eur J Hum Gen 2008; 16: 935-940.

18. Hanish F., Müller R., Grim D., et al. Frequency of calpain3c.550delA mutation in limb girdle muscular dystrophy type 2 and isolated hyperCKemia in German patients. Clin Neuropathol 2007; 26: 157-163.

19. Hermanova M., Zapletalova E., Sedlaèkova J., et al. Analysis of histopathologic and molecular pathologic findings in Czech LGMD2A patients. Muscle Nerve 2006; 33: 424-432.

20. Perez F., Vital A., Martin-Negrier M.L., et al. Diagnostic procedure of limb-girdle muscular dystrophies or calpainopathies: French cohort from a neuromuscular center (Bordeaux). Rev Neurol (Paris) 2010; 166: 502-508.

21. Politt C., Anderson L.V.B., Pogue R., et al. A phenotype of calpainopathy: diagnosis based on a multidisciplinary approach. Neuromuscul Disord 2001; 11: 287-296.

22. Richard I., Broux O., Allamand V., et al. Mutations in the proteolytic enzyme calpain 3 cause limb-girdle muscular dystrophy type 2A. Cell 1995; 81: 27-40.

23. Urtasun M., Saenz A., Roudaut C., et al. Limb-girdle muscular dystrophy in Guipuzcoa (Basque Country, Spain). Brain 1998; 121: $1735-1747$
24. Vainzof M., de Paula F., Tsanaclis A.M., et al. The effect of calpain 3 defficiency on the pattern of muscle degeneration in the earliest stages of LGMD2A. J Clin Pathol 2003; 56: 624-626.

25. Spencer M.J., Guyon J.R., Sorimachi H., et al. Stable expression of calpain 3 from a muscle transgene in vivo: immature muscle in transgenic mice suggests a role for calpain 3 in muscle maturation. Proc Natl Acad Sci U S A 2002; 99: 8874-8879.

26. Vattemi G., Tonin P., Neri M., et al. Calpain 3 deficiency presenting as fibre type disproportion. Neuropathol Apl Neurobiol 2009; 35: 614-617.

27. Fanin M., Nascimbeni A.C., Fulizio L., et al. The frequency of limb girdle muscular dystrophy 2A in northeastern Italy. Neuromuscul Disord 2005; 15: 218-224.

28. Milic A., Daniele N., Lochmüller H., et al. A third of LGMD2A biopsies have normal calpain 3 proteolytic activity as determined by an in vitro assay. Neuromuscul Disord 2007; 17: 148-156.

29. Beckman J.S., Richard I., Hillaire D., et al. A gene for limbgirdle muscular dystrophy maps to chromosome 15 by linkage analysis. CR Acad Sci III 1991; 312: 141-148.

30. Richard I., Brenguier L., Dinçer P., et al. Multiple independent molecular aetiology for limb-girdle muscular dystrophy type $2 \mathrm{~A}$ patents from various geographical origins. Am J Human Gen 1997; 60: 1128-1138.

31. Keira Y., Noguchi S., Minami N., et al. Localization of calpain 3 in human skeletal muscle and its alteration in limb-girdle muscular dystrophy 2 A muscle. J Biochem 2003; 133: 659-664.

32. Huang J., Fosberg N.E. Role of calpain in skeletal muscle protein degradation. Proc Natl Acad Sci U S A 1998; 95: 1210012105.

33. Tagawa K., Taya C., Hayashi Y., et al. Myopathy phenotype of transgenic mice expressing active site-mutate inactive p94 skeletal muscle-specific calpain, the gene product responsible for limb girdle muscular dystrophy type 2A. Hum Mol Genet 2000; 22: 1393-1402.

34. Zatz M., de Paula F., Starling A., et al. The 10 autosomal recessive limb-girdle dystrophies. Neuromuscul Disord 2003; 13: 532-544.

35. Duguez S., Bartoli M., Richard I. Calpain 3: a key regulator of the sarcomere? FEBS J 2006; 273: 3427-3436.

36. Chae J., Minami N., Jin Y., et al. Calpain 3 gene mutations: genetic and clinico-pathologic findings in limb-girdle muscular dystrophy. Neuromuscul Disord 2001; 11: 547-555.

37. Weller B., Carpenter S., Lochmüller H., Karpati G. Myopathy with trabeculated muscle fibers. Neuromuscul Disord 1999; 9: 208-214.

38. Keira Y., Noguchi S., Kurokawa R., et al. Characterization of lobulated fibers in limb girdle muscular dystrophy type $2 \mathrm{~A}$ by gene expression profiling. Neurosci Res 2007; 57: 513-521.

39. Todorova A., Georgieva B., Tournev I., et al. A large deletion and novel point mutations in the calpain 3 gene (CAPN3) in Bulgarian LGMD2A patients. Neurogenetics 2007; 8: 225-229.

40. Fanin M., Nardetto A.C., Nascimbeni A.C., et al. Correlations between clinical severity, genotype and muscle pathology in limb girdle muscular dystrophy type 2.J Med Genet 2009; 44: 609-614.

41. Guerard M.J., Sewry C.A., Dubowitz V. Lobulated fibers in neuromuscular diseases. J Neur Sci 1985; 69: 345-356. 
42. Bethlem J., Van Wijngarden G.K., De Jong J. The incidence of lobulated fibers in the facio-scapulo-humeral type of muscular dystrophy and the limb-girdle syndrome. J Neurol Sci 1973; 18: 351-356.

43. Figarella-Branger D., El-Dassouki M., Saenz A., et al. Myopathy with lobulated muscle fibers: evidence for heterogeneous etiology and clinical presentation. Neuromuscul Disord 2002; 12: 4-12.

44. Irodenko V.S., Lee H.S., de Armond S.J., et al. Adult nemaline myopathy with trabecular muscle fibers. Muscle Nerve 2009; 39: 871-875.

45. KumamotoT., Ueama H., Fujimoto S., et al. Clinicopathologic characteristics of polymyositis patients with numerous tissue eosinophils. Acta Neurol Scand 1996; 94: 110-114.

46. de Paula F., Vainzof M., Passos-Bueno M.R., et al. Clinical variability in calpainopathy: what makes the difference? Eur J Hum Gen 2002; 10: 825-832.

47. Yajima Y., Kawashima S. Calpain function in the differentiation of mesenchymal stem cells. Biol Chem 2002; 383: 757-764.

48. Engel A.G., MacDonald R.D. Ultrastructural reactions in muscle disease and their light-microscopic correlates. In: Walton J.N., Canal N., Scarlato G. [eds.]. Muscle diseases (International Congress Series No.199). Excerpta Medica, Amsterdam 1970, pp. 71-89.

49. Olivé M., Shatunov A., Gonzalez L., et al. Transcription-terminating mutation in telethonin causing autosomal recessive muscular dystrophy type $2 \mathrm{G}$ in an European patient. Neuromuscul Disord 2008; 18: 929-933.

50. Saenz A., Leturcq F., Cobo A.M., et al. LGMD2A: genotypephenotype correlations based on a large mutational survey on the calpain 3 gene. Brain 2005; 128: 732-740.

51. Nadaj-Pakleza A., Kierdaszuk B, Kamińska A. The role of skeletal muscle biopsy in the diagnosis of neuromuscular disorders. Neurol Neurochir Pol 2010; 44: 481-491.

52. Carpenter S., Karpati G. [eds.]. Pathology of skeletal muscle. Oxford University Press, Oxford 2001, pp. 156-157.

53. Fanin M., Fulizio L., Nascimbeni A.C., et al. Molecular diagnosis in LGMD2A: mutation analysis or protein testing. Hum Mutat 2004; 24: 52-62. 